\title{
Teachers' Views on Organizational Deviance, Psychological Ownership and Social Innovation*
}

\author{
Türkan Argon*, Serkan Ekinci \\ Faculty of Education, Abant Izzet Baysal University, Turkey
}

Copyright $(2016$ by authors, all rights reserved. Authors agree that this article remains permanently open access under the terms of the Creative Commons Attribution License 4.0 International License

\begin{abstract}
This study aimed to identify Bolu central district secondary school teachers' views on organizational deviance, psychological ownership and social innovation and to determine whether these views were related. The universe of the study conducted with relational screening model was composed of 360 teachers employed in Bolu central district secondary schools. Psychological Ownership, Organizational Deviance and Social Innovation Scales were used as data collection tools. Means, standard deviation and Spearman's Rho correlation analysis were used in data analysis. According to research results it was found that teachers displayed organizational deviance behaviors towards themselves or their coworkers albeit in low levels and agreed to the items related to psychological ownership and social innovation. Negative, low level and significant relationships were detected between teachers' views on organizational deviance towards self and coworkers, psychological ownership and social innovation. Also, a positive, medium level significant relationship was found between psychological ownership and social innovation.
\end{abstract}

Keywords Organizational Deviance, Psychological Ownership, Social Innovation, Teacher

\section{Introduction}

Digressing from habitual behaviors in organizations may be an undesired and destructive event and it carries the potential to destroy the operability of organizations. Of course it is not unnatural when individual errors, mistakes or negative situations appear in work life, however, when these become repeated and perpetual in nature, they may reduce the motivation of staff that behave according to goals, embrace their organizations and are involved with continuous self-development. In this context, when teachers in educational organizations renew themselves, adopt and embrace their schools, a quality educational environment will develop and in this way, it is expected that teachers will be able to achieve more than what is specified in their job descriptions with the existence of an agreeable, inoffensive and warm school environment where relationships are civilized and courteous without becoming highly bureaucratic.

\subsection{Organizational Deviance, Psychological Ownership and Social Innovation}

Existence of unrecognized, disruptive and obstructive situations at work life may result in individual and organizational damages. As an example, organizational deviance behaviors [39] generating from relationships between managers-staff or among coworkers are intentional behaviors of the members of the organization [15]; [36] to hamper the daily operations of the organization and these deviant behaviours damage the organization, staff or both and affect organizational norms in serious ratios [29]. The deviant behaviors, which aim to disturb coworkers with small scale behaviors such as gossiping, theft or sabotage [10], are affected by inability to meet the expectations of staff in terms of wages, promotions, ambiguity of job definitions and roles and arbitrary practices of managers [9] as well as different perceptions of justice and factors that may create pressures in the work place[11]. Whatever the reason behind the deviant behavior; organizational deviance is an undesired and negative situation for organizations and staff. Organizational deviance behaviors are deliberate staff behaviors in written or oral verbal that are not appropriate for the values and expectations of the organization, violate the norms and damage the functions, structure, relationships and members of the organization [9]; [19]. Including practices that will reduce or eliminate such organizational deviance behaviors in the staff and create a positive organizational climate is crucial for organizational goals. Ensuring that staff feel organizational ownership, experience psychological commitment and regard the organization as a part of their identity [18] will both increase organizational achievement and decrease organizational deviance behaviors.

As an extension of individual's sense of self, feeling of ownership is the perception of an object as "my" or "our" [27], enables individuals to form connections between the 
self and targets and finds place in almost all societies [37]. In this context, psychological ownership may be oriented towards attitudes and behaviors [32] or to the organization, field of study, group, ideas or work [34] it may also be oriented towards financial or monetary concepts [35]. When individuals start to feel themselves as a part of the organization, the psychological ownership that is generated is the state of feeling as if they own the intended target or a part of it [25] and it is a feeling that is invoked without formal or legal ownership [17]. In this sense, it includes voluntarism and allows the staff to offer their skills and tasks to the service of the organization without external pressures and without waiting for any return [8]. Psychological ownership facilitates the presentation of behaviors for the benefit of the organization and enables the emergence of non-obligatory extra roles to ensure this [33]. Organizations prefer to observe this behavior in their staff and strive to develop policies and practices towards the organization and their staff. This necessitates continuous organizational development as well. Organizations expect their staff to develop and renew as well in order to increase their organizational contribution since the staff that is renewed as a result of continuous change and innovation will have significantly higher organizational contribution compared to others. Also, innovative staff is composed of the coworkers that research, question and contribute to organizational performance.

Innovation is a concept studied on its own in the literate. In individual or organizational terms, innovation can be studied in relation to creativity and technological and social aspects in terms of service, products and process. Social innovation has been developed and spread by socially motivated organizations for innovative activities and services that aim to meet a social need [20]. It expresses production, selection and implementation of ideas mutually by the individuals who contribute to the efforts to solve social problems with a common effort [7]. In another definition, social innovation is explained as the production and implementation of new ideas about how activities or social interactions among individuals to realize one or more common goals should be organized [21]. The most important prerequisite for social innovation is the honest intentions of people who work independently form executive efforts used to promote innovation in organizations [6]. One of most crucial contributions of social innovation is the fact that it enables individuals to become aware of the responsibilities related to social problems and their roles in solving them [16]. In short, social innovation is the sum of innovations that create qualitative and quantitative positive changes in human life [28]. Social innovation does not only focus on outcomes but also on the process, generates beneficial and long term results, aims to change the relationships among the stakeholders included in innovation and requires the related stakeholders to take part in the design, practice and adoption of social innovation process to obtain significant results [5].

Characteristics of social innovations are as follows: only collective actions may bring about social innovation, these actions follow one another; development is triggered by a specific driving power such as technological or economic innovations, social innovations are based on individuals' subjective innovation perceptions, they focus on changes in attitudes, perceptions and behaviors, they are not based on economic anxieties and do not have economic expectations [22].

While psychological ownership with important roles in the development of elements related to individuals [26] has positive relationships with adopting new technologies or systems [24]; [3], it has negative relationships with deviant or negative behaviors [2]. In this sense, psychological ownership has immense individual or organizational impact in positive outcomes such as taking additional responsibility, organizational commitment and citizenship behavior, volunteering, self-devotion via personal sacrifices, risk taking and increased productivity and performance [8]. It is believed that the three concepts which are addressed by the current study are individually significant for teachers who are the staff of educational organizations. High psychological ownership and social innovation levels in teachers are significant since they will contribute to the characteristics of future generations by increasing teachers' contributions to schools. The process of education is a renewal process in addition to being a process that enables the acquisition of new behaviors. The close relationship between education and social innovation will be clearer when the qualitative and quantities positive changes in individuals brought about by social innovation are taken into consideration. This is also important in increasing the quality of human resources that will take part in working life in the future. On the other hand, the existence of organizational deviance in teachers will harm organizational success by both reducing teacher productivity and damaging interpersonal peace and harmony. This situation will result in damages to goal realization and organizational achievement. These negative behaviors are generally displayed with staff that has little or no contribution to the organization. On the other hand, teachers with high psychological ownership levels are not expected to display organizational deviance behaviors and they are expected to continuously renew and develop themselves. In this context, the current study aimed to present teachers' views related to psychological ownership, organizational deviance and social and determined whether there were relationships between the views. Being the first study in the field, it is believed to be important due to the contributions it will provide.

\section{Purpose of the Study}

This study aimed to present teachers' views related to psychological ownership, organizational deviance and social and determine whether there were significant relationships between the views. In this context, the study sought answers to the following questions:

1. What are Bolu central district secondary school teachers' 
views on organizational deviance, psychological ownership and social innovation?

2. Are there significant relationships between Bolu central district secondary school teachers' views on organizational deviance, psychological ownership and social innovation?

\section{Method}

\subsection{Research Model}

The study conducted by using relational screening model aimed to identify the existence and/or degree of change between two or more variables [13].

\subsection{Universe of the Study}

The universe of the study was composed of 360 voluntary teachers employed in Bolu central district secondary schools in 2015-2016 academic year. $60,6 \%$ of the participating teachers were females and $39,4 \%$ were males; $20,3 \%$ were in the age range of $20-30$ years, $45 \%$ were in the age range of $31-40$ years, $27,5 \%$ were in the age range of $41-50$ years and $7,2 \%$ were in the age range of 51 and older; $37,5 \%$ had $1-10$ years seniority, $40,8 \%$ had $11-20$ years seniority, $21,7 \%$ had 21 years and higher seniority; $90 \%$ had undergraduate degrees and $10 \%$ had graduate degrees.

\subsection{Data Collection Tool}

Psychological Ownership, Organizational Deviance and Social Innovation Scales were used in the study as data collection tools. Psychological Ownership Scale was developed by Van Dyne and Pierce [34] and adapted to
Turkish by Ökten [23]. The scale has a single dimension with 7 items and its Cronbach Alfa value is .91. Cronbach Alfa internal consistency coefficient for the current study was found to be .78. Organizational Deviance Scale was developed by Bennett and Robinson[40] and adapted to Turkish by İyigün [14]. The 13-item scale has two dimensions: organizational deviance in self and organizational deviance in coworkers. These dimensions have two subscales: organizational deviance against productivity and interpersonal organizational deviance. Cronbach Alpha internal consistency coefficient for the scale was found to be 89 . This study calculated Cronbach Alpha values to be .92 for coworkers and .88 for self. The last scale used in the study, Social Innovation Scale was developed by Halaç, Eren and Bulut [30] and includes a single dimension and 8 items. Cronbach Alpha internal consistency coefficient for the scale was found to be .86. Cronbach Alpha internal consistency coefficient for this study was found to be .74 .

\subsection{Data Analysis}

Research data were analyzed by using SPSS for Windows 22.0 program. Data distribution was examined with Kolmogorov-Smirnov test before data analysis and it was found that the data did not display normal distribution. Therefore, non-parametric tests were used in analysis. In this direction, means and standard deviation were utilized to identify teachers' views and Spearman's Rho correlation analysis was conducted to determine the relationships between organizational deviance, psychological ownership and social innovation. Level of significance was accepted as .05 in the study.

\section{Findings}

\subsection{Teachers' Views on Organizational deviance, Psychological Ownership and Social Innovation Scales}

Table 1. Descriptive Statistics for Organizational Deviance, Psychological Ownership and Social Innovation Scales

\begin{tabular}{lllll}
\hline & \multicolumn{1}{c}{ Scales and Dimensions } & N & $\overline{\mathrm{X}}$ & $\mathbf{S S}$ \\
\hline \multirow{3}{*}{$\begin{array}{l}\text { Organizational } \\
\text { Deviance Scale }\end{array}$} & Organizational Deviance in coworkers-General & 360 & 1,47 & 0,54 \\
& Organizational Deviance Against Productivity & 360 & 1,56 & 0,59 \\
& Interpersonal Organizational Deviance & 360 & 1,36 & 0,58 \\
\cline { 2 - 6 } & Organizational Deviance in Self-General & 360 & 1,23 & 0,39 \\
& Organizational Deviance Against Productivity & 360 & 1,56 & 0,59 \\
& Interpersonal Organizational Deviance & 360 & 1,36 & 0,58 \\
\hline Psychological Ownership Scale & 360 & 3,98 & 0,91 \\
\hline Social Innovation Scale & & 360 & 4,12 & 0,73 \\
\hline
\end{tabular}


Based on Table 1, teachers' views on organizational deviance scale presented low level organizational deviance values with organizational deviance against productivity $\bar{X}=1,56$, interpersonal organizational deviance $\bar{X}=1,36$ and in total $\overline{\mathrm{X}}=1,47$. These values pointed that teachers had unusual organizational behaviors against their coworkers albeit at low levels. Additionally, it can be argued that organizational deviance against productivity was higher than interpersonal organizational deviance. When teachers' views on organizational deviance in self were examined, it was found to be low with $\overline{\mathrm{X}}=1,23$ in total, $\overline{\mathrm{X}}=1,36$ for organizational deviance against productivity and $\overline{\mathrm{X}}=1,56$ for interpersonal organizational deviance. These findings showed that teachers display organizational deviant behaviors towards self-albeit at low levels. As was the case in organizational deviance for coworkers, organizational deviance against productivity was higher compared to interpersonal organizational deviance.

Teachers' views related to psychological ownership presented agreement with $\bar{X}=3,98$. This finding pointed to the fact that teachers felt high levels of ownership-although not completely- to the organizations they worked in. Teachers' views social innovation presented agreement with $\overline{\mathrm{X}}=4,12$. In line with this finding, it was observed that teachers were open to social innovation. However, when assessed in individual terms, teachers' views on social innovation were higher than their views on psychological ownership.

\subsection{The Relationship between Organizational Deviance, Psychological Ownership and Social Innovation}

The relationship between teachers' views on organizational deviance, psychological ownership and social innovation were addressed separately with the two dimensions of organizational deviance: Organizational Deviance for Coworkers and Organizational Deviance for Self.

Table 2 points to several relationships between teachers' views on organizational deviance for coworkers and psychological ownership and social innovation. Findings related to these relationships are as follows: There was a low level, negative and significant relationship between organizational deviance for coworkers in general and psychological ownership $(\mathrm{r}=-, 265 ; \mathrm{p}<.01)$ and social innovation $(r=-, 207 ; p<.01)$. Similarly, a low level, negative and significant relationship was found between organizational deviance against productivity and psychological ownership $(\mathrm{r}=-, 216 ; \mathrm{p}<.01)$ and social innovation $(\mathrm{r}=-192 ; \mathrm{p}<.01)$ and between interpersonal organizational deviance and psychological ownership $(\mathrm{r}=-, 258 ; \mathrm{p}<.01)$ and social innovation $(\mathrm{r}=-, 175 ; \mathrm{p}<.01)$. Based on these findings, it can be argued that teachers' organizational deviance for coworkers decreased at low levels when their psychological ownership and social innovation levels increased or that their organizational deviance for coworkers increased at low levels when their psychological ownership and social innovation levels decreased. A medium level positive and significant relationship was detected between teachers' views on psychological ownership and social innovation $(\mathrm{r}=384$; $\mathrm{p}<.01$ ). This finding showed that teachers' social innovation levels increase at medium levels when their psychological ownership levels increased.

Table 3 presents negative relationships between teachers' views on organizational deviance for self and psychological ownership and social innovation. Findings related to these relationships are as follows: There was a low level, negative and significant relationship between organizational deviance for self in general and psychological ownership $(\mathrm{r}=-, 164$; $\mathrm{p}<.01)$ and social innovation $(\mathrm{r}=-, 180 ; \mathrm{p}<.01)$. A low level, negative and significant relationship was found between the subscales organizational deviance against productivity and psychological ownership $(\mathrm{r}=-, 216 ; \mathrm{p}<.01)$ and social innovation $(\mathrm{r}=-192 ; \mathrm{p}<.01)$ and between interpersonal organizational deviance and psychological ownership $(\mathrm{r}=-, 258 ; \mathrm{p}<.01)$ and social innovation $(\mathrm{r}=-, 175 ; \mathrm{p}<.01)$. Based on these findings, it can be argued that teachers' organizational deviance for self-decreased at low levels when their psychological ownership and social innovation levels increased or that their organizational deviance for self-increased at low levels when their psychological ownership and social innovation levels decreased.

Table 2. Correlation Analysis (Spearman's Rho) for Teachers' Views on Organizational Deviance for Coworkers, Psychological Ownership and Social Innovation

\begin{tabular}{lccc}
\hline & & Psychological Ownership & Social Innovation \\
\hline Organizational Deviance for Coworkers-General & $\mathrm{r}$ &,$- 265^{* *}$ &,$- 207^{* *}$ \\
Organizational Deviance Against Productivity & $\mathrm{r}$ &,$- 216^{* *}$ &,$- 192^{* *}$ \\
Interpersonal Organizational Deviance & $\mathrm{r}$ &,$- 258^{* *}$ &,$- 175^{* *}$ \\
Psychological Ownership & $\mathrm{r}$ & 1 &, $384^{* *}$ \\
\hline$* * \mathrm{p}<.01$ & & &
\end{tabular}

Table 3. Correlation Analysis (Spearman's Rho) for Teachers' Views on Organizational Deviance for Self, Psychological Ownership and Social Innovation

\begin{tabular}{llcc}
\hline & & Psychological Ownership & Social Innovation \\
\hline Organizational Deviance for Self-General & $\mathrm{r}$ &,$- 164^{* *}$ &,$- 180^{* *}$ \\
Organizational Deviance against Productivity & $\mathrm{r}$ &,$- 216^{* *}$ &,$- 192^{* *}$ \\
Interpersonal Organizational Deviance & $\mathrm{r}$ &,$- 258^{* *}$ &,$- 175^{* *}$ \\
\hline
\end{tabular}

$$
* * \mathrm{p}<.01
$$




\section{Discussion, Result and Suggestions}

Research results presented that teachers' organizational deviance for coworkers and self were found to be at low levels both in general and in interpersonal organizational deviance and organizational deviance against productivity sub dimensions. This finding pointed to the existence of unusual and negative organizational behaviors in teachers towards the self and coworkers- albeit at low levels. When this result was considered in terms of scale items; organizational deviance behaviors were observed in the framework of Organizational Deviance against Productivity (such as behaviors deviating from goals; taking longer break than is acceptable at the workplace, calling in sick when one is not ill, spending too much time fantasizing or daydreaming instead of working, working slower intentionally than one can work, leaving work early without permission, coming in late to work without permission or justification, putting little effort into work etc. ). Similarly, low level organizational deviance behaviors were observed in teachers in the framework of interpersonal organizational deviance (saying something hurtful to coworkers at school, cursing, making fun of someone, acting rudely toward someone at work, embarrassing someone, making an ethnic, religious, or racial remark at work etc. ). One of the interesting findings of the study was the fact that Organizational Deviance against Productivity was partially higher than Interpersonal Organizational Deviance. Whether they are against productivity or they are interpersonal, organizational deviance behaviors may hinder goal oriented operations of schools and teacher actions towards school goals. These behaviors may also generate an environment of unrest by negatively affecting the school climate. These behaviors that will damage to relationships among teachers will estrange teachers who need to work with a team spirit. This situation is contrary to the spirit and nature of the educational process. While the results of the current study overlap with the findings of Avc1 [1] and Girgin-Köse's [12] study on different sectors and personnel, they differentiate with the findings of Yalap' [38]. Also the finding that teachers have higher level organizational deviance against productivity compared to interpersonal organizational deviance is completely corresponds to Bayın and Yeşilaydın's [4] research results.

Teachers agreed to statements related to psychological ownership. This result showed that they felt ownership to their organizations at high levels-although not fully. This finding can be regarded as an indicator that teachers feel as a part of their schools and regard the goals of the school as their own. The fact that psychological ownership feeling includes volunteering is crucial for the educational process since it allows teachers to offer their skills and tasks to school without the influence of external factors and without expecting anything in return [8]. Teaching profession is done conscientiously and requires volunteering. It is highly probable that teachers with high levels of psychological ownership will embrace the profession more and display additional roles voluntarily. In addition, considering the fact that psychological ownership influences the continuity of extra and positive roles, it can be inferred that psychological ownership results in displaying positive attitudes and behaviors.

As was the case in psychological ownership, teachers agreed to statements related to social innovation. When considered in individual terms, teachers' views on social innovation were even higher than those related to psychological ownership. This finding shows that teachers are open to social innovation. Social innovation is a type of innovation geared towards innovative activities and services developed and spread by socially oriented organizations with the aim of meeting a social need [20]. Since educational organizations are social organizations with the goal of serving people, social innovation can be easily accepted and implemented in these organizations. Social innovation is a variation that creates positive changes in human life [28]. In this context, research results show that teachers reflect the continuous change and development -the requirement of the profession- on their profession in their work environments. As a matter of fact, it is crucial for the success of organizations to have fair personnel with innovative skills, attitudes and behavior [31]. High level social innovation in teachers will facilitate the presentation of new and different ideas by reorganizing the activities and social interactions among them in order to realize school goals. Schools can develop and renew themselves with the creative and new ideas of teachers. Therefore, increasing the social innovation behaviors' of teachers at educational organizations will amplify their shares in the realization of school goals. Similarly and parallel to the findings of the current study, Demirkaya and Şimşek-Kandemir [8] also found in their studies related to business field that psychological ownership level was above the mean.

The study reported a low level, negative and significant relationship between organizational deviance for self and for coworkers in general and psychological ownership and social innovation. Based on this result it argued that increases in teachers' psychological ownership and social innovation levels will reduce their organizational deviance towards self and towards coworkers, albeit at low levels. In other words, decreases in teachers' psychological ownership and social innovation levels will increase their organizational deviance towards self and towards coworkers, albeit at low levels. Also, a medium level, positive and significant relationship was detected between teachers' views on psychological ownership and social innovation. This result shows that increases in teachers' psychological ownership increase their social innovation levels at a medium level. Taking the results of teachers' views into consideration as a whole, teachers with high psychological ownership towards their schools who regard themselves as a part of their schools are not expected to display organizational deviance behaviors such as leaving work without permission, coming in to work late, neglecting or slowing tasks, saying hurtful things to coworkers, curding, acting rudely, making fun of 
someone or embarrassing someone. As a matter of fact, psychological ownership has negative relationships with deviant or negative behaviors [2]. Research results also support this finding. On the other hand, teachers with high psychological ownership levels are expected to continuously renew and develop themselves. Innovative teachers are the ones who look for methods to create innovation $\mathrm{s}$ for themselves and for their schools, search for ways to solve problems, seek methods for social cooperation and participation, create social values and generate new ideas to make schools more active. Innovative teachers do all these without expecting any return just to be beneficial to others. All these qualities are immensely important for the educational process and for the success of schools.

The suggestions developed in line with research results are as follows:

1. Intellectual capitals of teachers may be increased by providing culture-art activities in order to minimize organizational deviance at schools;

2. The issue of organizational deviance should be included in the meeting agenda and the sensitivity of the matter should be emphasized so as not to experience deviant behaviors at schools. When these types of behaviors' are displayed no compromises should be allowed and necessary sanctions should be implemented.

3. Continuity of adopting high level innovation can be ensured for teachers by providing governmental support such as using tax exemption in acquiring technological products.

4. In order to ensure professional development of teachers with high psychological ownership levels, they can be supported to attend graduate programs.

5. Research can be done to comprehend how teachers with high psychological ownership levels manage to obtain psychological ownership and the results can be shared at schools.

\section{Note}

*The abstract of this paper was presented at 2nd International Conference on Lifelong Learning and Leadership for All (ICLEL-16), in Liepaja on July, 21-23, 2016.

\section{REFERENCES}

[1] Avc1, N. (2008). Konaklama İsletmelerinde Örgütsel Öğrenme, İş Tutumları ve Örgütsel Sapma Arasındaki İlişkinin Analizi. Yayımlanmamış Doktora Tezi. Dokuz Eylül Üniversitesi Sosyal Bilimler Enstitüsü İzmir.

[2] Avey, J. B., Avolio, B. J., Crossley, C. D., \& Luthans, F. [2]. Psychological ownership: Theoretical extensions, measurement and relation to work outcomes. Journal of Organizational Behavior, 30(2), 173-191.
[3] Barki, H., Paré, G., \& Sicotte, C. (2008). Linking IT implementation and acceptance via the construct of psychological ownership of information technology. Journal of Information Technology, 23(4), 269-280.

[4] Bayın, G. ve Terekli Yeşilaydın, G. (2014) Hemşirelerde örgütsel sapma davranışının analizi: Bir üniversite hastanesi örneği. İşletme Araştırmaları Dergisi, 6(3), 81-107.

[5] Bekkers, V.J.J.M., Tummers, L.G. \& Voorberg W.H. (2013). From public innovation to social innovation in the public sector: A literature review of relevant drivers and barriers. Rotterdam: Erasmus University Rotterdam. Paper to be presented at EGPA Conference Edinburg, 11-13 September.

[6] Bright, D. S. \& Godwin, L.N. (2010). Encouraging social innovation in global organizations: Integrating planned and emergent approaches, Journal of Asia-Pacific Business, 11(3), 179-196.

[7] Dawson, P. and Daniel, L. (2010). Understanding social innovation: a provisional Framework. International J. Technology Management, 51 (1), 139-158.

[8] Demirkaya, H. ve Şimşek Kandemir, A. (2014). 21. Yüzyılın anahtar rekabet faktörü olan psikolojik sahiplenme üzerine bir işletme incelemesi. Çalışma Dünyası Dergisi, 2(3), 7-21.

[9] Demir, M. ve Tütüncü, Ö. (2010). Ağırlama işletmelerinde örgütsel sapma ile işten ayrılma eğilimi arasındaki ilişki. Anatolia: Turizm Araştırmaları Dergisi, 21 (1), 64-74.

[10] Dunlop, P.D., and Lee, A.K. (2004). Workplace deviance, organizational citizenship behavior, and business unit performance: The bad apples do spoil the whole barrel. Journal of Organizational Behavior, 25, 67-80.

[11] Fox, S., Spector, P.E., \& Miller, D. (2001). Counterproductive work behavior (CWB) in response to job stressors and organizational justice: Some mediator and moderator tests for autonomy and emotions. Journal of Vocational Behavior, 59, 291-309.

[12] Girgin-Köse, S. (2013). Ortaokul Öğretmenlerinin Örgütsel Sapma ve Stratejik Liderlik Arasındaki İlișki Üzerine Algıları: İzmir İli Örneği. Yayımlanmamış Yüksek Lisans Tezi. Dokuz Eylül Üniversitesi. Eğitim Bilimleri Enstitüsü, İzmir.

[13] Karasar, N. (2011). Bilimsel Araştırma Yöntemi. Ankara: Nobel Yayınları.

[14] İyigün, N. Ö. (2011). Psikolojik Kontratın Örgütsel Sapma Üzerindeki Etkisinde Kișilik Özelliklerinin Rolü ve Bir Araştırma. Yayımlanmamış Doktora Tezi. Marmara Üniversitesi, Sosyal Bilimler Enstitüsü, İstanbul.

[15] Lawrence, T.B. and Robinson, S.L. (2007). Ain't misbehavin: Workplace deviance as organizational resistance. Journal of Management, 33(3), 378-394.

[16] Lettice, F. and Parekh, M. (2010). The social innovation process: themes, challenges and implications for practice. International Journal Technology Management, 51 (1), 139-158.

[17] Mayhew, M. G., Ashkanasy, N. M., Bramble, T. \& Gardner, J. (2007). A study of the antecedents and consequences of psychological ownership in organizational settings. The Journal of Social Psychology, 147(5), 477-500.

[18] McIntyre, N., Srivastava, A. \& Fuller, J.A. (2009). The relationship of locus of control and motives with 
psychological ownership in organizations. Journal of Managerial Issues, 21(3), 383-401.

[19] Muchinsky P. M. (2006). Psychology Applied to Work, (International Student Edition), US: Thomson Wadsworth.

[20] Mulgan, G., Tucker, S., Ali, R. \& Sanders, B. (2007). Social innovation: What it is, why it matters and how it can be accelerated., Skoll Centre for Social Entrepreneurship, Said Business School, Oxford University, The Young Foundation, working paper. www .sbs.ox.ac.uk/skoll. 1-51. (25/05/2016).

[21] Mumford, M.D. (2002). Social innovation: Ten cases from Benjamin Franklin. Creativity Research Journal, 14 (2),253-266.

[22] Neumeier, S. (2012). Why do social innovations in rural development matter and should they be considered more seriously in rural development research? - Proposal for a Stronger Focus on Social Innovations in Rural Development Research. Sociologia Ruralis, 52, (1), 48-69.

[23] Ötken, A. B. (2015). Algılanan örgütsel destek ve psikolojik sahiplenme arasındaki ilişki ve bu ilişkide örgütsel adaletin rolü. Hacettepe Üniversitesi İktisadi ve İdari Bilimler Fakültesi Dergisi, 33 (2), 113-140.

[24] Paré, G., Sicotte, C., \& Jacques, H. (2006). The effects of creating psychological ownership on physicians' acceptance of clinical information systems. Journal of the American Medical Informatics Association, 13(2), 197-205.

[25] Pierce, J. L., Kostova, T. \& Dirks, K. T. (2001). Toward a theory of psychological ownership in organizations. Academy of Management Review, 26(2), 298-310.

[26] Pierce, J. L., Kostova, T., \& Dirks, K. T. (2003). The state of psychological ownership: Integrating and extending a century of research. Review of General Psychology, 7(1), 84-107.

[27] Pierce, J. L., O'driscoll, M. P., \& Coghlan, A. M. (2004). Work environment structure and psychological ownership: the mediating effects of control. The Journal of Social Psychology, 144(5), 507-534.

[28] Pol, E. and Ville, S .(2009). Social innovation: Buzz word or enduring term? The Journal of Socio-Economics, 38, 878-885.

[29] Robinson, S.L., and Bennett, R.J. (1995). A typology of deviant workplace behaviors: A multidimensional scaling study. Academy of Management Journal, 38, 555-572.
[30] Seçkin Halaç, D., Eren, H. ve Bulut, Ç. (2014). Sosyal yenilikçilik: Bir ölçek geliştirme çalışması. Hacettepe Üniversitesi İktisadi ve İdari Bilimler Fakültesi Dergisi, 32(1), 165-190.

[31] Titrek, O. (2015). The level of innovation management of school principals' in Turkey. Anthropologist, 19(2), 449-456.

[32] Wagner S. H, Parke C. P \& Christiansen N. D. (2003). Employees that think and act like owners: Effects of ownership beliefs and behaviors on organizational effectiveness. Personnel Psychology, 56, 847-871.

[33] Van Dyne, L., Cummings, L.L. \& Parks, J.M., (1995). Extra-role behaviors: In pursuit of construct and definitional clarity (A bridge over muddied waters). Eds. L. L. Cummings \& B. M. Staw). In Research In Organizational Behavior. pp. 215-285. Greenwich, CT: JAI Press.

[34] Van Dyne, L., \& Pierce, J. L. (2004). Psychological ownership and feelings of possession: three field studies predicting employee attitudes and organizational citizenship behavior. Journal of Organizational Behavior, 25(4), 439-459.

[35] Vandewalle, D., Van Dyne, L., \& Kostova, T. (1995). Psychological ownership: An empirical examination of its consequences. Group \& Organization Management, 20(2), 210-226.

[36] Vardi, Y. and Wiener, Y. (1996). Misbehavior in organizations: a motivational framework. Organization Science, 7 (2) 151-165.

[37] Yeşil, Ü., Bancar, A. ve Budak, G. (2015). Psikolojik sahiplik kavramına ilişkin bir literatür incelemesi. Eskişehir Osmangazi Üniversitesi Sosyal Bilimler Dergisi, 16(2), 59-82.

[38] Yalap, O. (2016). Çalışanların Örgütsel Adalet Algılamalarının Örgütsel Sapma Davranıșları Üzerinde Etkisi: Tekstil Sektöründe Bir Araştırma. Yayımlanmamış Yüksek Lisans Tezi. Gaziosmanpaşa Üniversitesi Sosyal Bilimler Enstitüsü, İstanbul.

[39] Yeşiltaş, M., Çeken, H. ve Sormaz, Ü. (2012). Etik liderlik ve örgütsel adaletin örgütsel sapma davranışları üzerindeki etkisi. Muğla Üniversitesi Sosyal Bilimler Enstitüsü Dergisi, 28, 18-39.

[40] Bennett, R. J., \& Robinson, S. L. (2000). Development of a measure of workplace deviance. Journal of Applied Psychology, 85, 349-360. 